CONTRIBUTIONS FROM THE METHODOLOGICAL PERSPECTIVE OF ARTSBASED RESEARCH AND A/R/TOGRAPHY FOR RESEARCH IN EDUCATION

\author{
Marilda Oliveira de Oliveira" \\ Universidade Federal de Santa Maria (UFSM) \\ Leonardo Augusto Charréu** \\ Universidade Federal de Santa Maria (UFSM)
}

\begin{abstract}
This text analyses the methodological perspective conceptually known as Arts-based Research (ABR) in a broader way and artography in a more specific way. In Brazil ABR is known as Pesquisa (on Investigacão) Baseada nas Artes ${ }^{1}$ (PBA), or Pesquisa Educacional Baseada nas Artes (PEBA), or yet Investigaşão Educacional Baseada nas Artes (IEBA). In Spanish-speaking countries the concept is explored as Investigación Basada en las Artes (IBA) and in the English-language countries Arts-Based Educational Research (ABER) or simply Arts-Based Research (ABR). A/r/graphy is a kind of "Arts-based Research". Initially we will detail the epistemological field of social constructionism and the notion of "voice" and later we deal with "Arts-Based Research", its link with $\mathrm{a} / \mathrm{r} /$ graphy and the contribution of both to research in education.
\end{abstract}

Keywords: Research. Methodologies. Education. Arts.

http://dx.doi.org/10.1590/0102-4698140547

"Doctor in Art History by the Universidade de Barcelona, Spain. Associate Professor of the Graduate Program in Education at the Universidade Federal de Santa Maria (PPGE/UFSM, RS). Leader of GEPAEC - Group of Studies and Research in Arts, Education and Culture. E.mail: oliveira.marilda27@gmail.com.

"Doctor in Education by the Universidade de Évora, Portugal. Assistant Professor of the Graduate Program in Education at the Universidade Federal de Santa Maria (PPGE/UFSM, RS). Vice-leader of GEPAEC . Group of Studies and Research in Arts, Education and Culture. E.mail: leonardo.charreu@gmail.com. 


\section{CONTRIBUIC̄̃̃ES DA PERSPECTIVA METODOLÓGICA “INVESTIGAC̣ÃO BASEADA NAS ARTES" E DA A/R/TOGRAFIA PARA AS PESQUISAS EM EDUCAÇÃO}

RESUMO: Este texto pretende abordar conceitualmente a perspectiva metodológica conhecida como Arts-Based Research (ABR) de uma forma mais ampla e a a/r/tografia de uma forma mais específica. No Brasil a ABR é conhecida como Pesquisa (ou Investigação) Baseada nas Artes (PBA), ou Pesquisa Educacional Baseada nas Artes (PEBA), ou ainda Investigação Educacional Baseada nas Artes (IEBA). Nos países de língua espanhola é explorada como Investigación Basada en las Artes (IBA) e nos países de língua inglesa, Arts-Based Educational Research (ABER) ou simplesmente Arts-Based Research (ABR). A a/r/tografia é uma das formas de "investigação baseada nas artes". Inicialmente, detalharemos o campo epistemológico do construcionismo social e a noção de "voz" para posteriormente tratar da "investigação baseada nas artes", seu vínculo com a a/r/tografia e o contributo de ambas para as pesquisas em educação.

Palavras-chave: Pesquisa. Metodologia. Educação. Artes.

\section{SITUATING AND VALUATING THE METHODOLOGIES, CLARIFYING ACRONYMS}

There are many designations, and their acronyms, that the readers may have to deal with in their research if we take into account the new contemporary methodologies. Especially those in which the art, and the phenomena derived from it, may be positioned in an important centrality, whatever the environment or the manifestation support and whatever their role in the research.

In fact, the apparent diversity of "artistic" research methodologies, some of which we seek to address in this text, is proof of the vitality currently going through the methodological field of research of a broad transdisciplinary area that spans education and the arts, in a broad sense, and no longer identifies itself entirely with the classic research methodologies.

As Eisner considered (1998, p. 16):

[...] The arts and humanities provided a long tradition of ways to describe, interpret, and appreciate the world: history, art, literature, dance, theatre, poetry and music are some of the most important ways in which human represented and have configured their experiences. These forms were never significant for qualitative inquiry for reasons that have to do with a limited and limiting conception of knowledge.

It seems clear that these conceptions of knowledge are changing, and it is relevant that some of the higher education institutions - to which we will refer later - more prominent in the acceptance and exploration of these new methodologies, are also at the forefront of the overall production of knowledge considered of 
reliable quality in other scientific areas. This means that the generation and development of new investigative platforms that have art as an important reference is not a marginal phenomenon of universities and peripheral academic centres. On the contrary; they are now being generated by prestigious institutions. These institutions accepted the risk of the difference in production and research of alternative pathways, and this attitude only ennobles them because it is, in fact, very close to the foundational idea, or the concept, of university.

It is a fact that many current researchers do not see, among the available research methodologies, one that has a more suitable methodological framework to support their research, which has resulted in an exponential growth of arts-based methodologies seeking to fill that gap. This is aggravated by the growth and affirmation of art education within the university and the graduate programs in art, and related areas, that, naturally, enforce the research priority.

Going a little bit deeper into the issue of the definition of the acronyms constellation that populate our study, we believe there are, however, certain subtle characteristics and certain identity nuances that justify that an arts-based educational research (ABER/ English acronym $=$ PEBA Portuguese acronym) does not have exactly the same goals, or produces the same results, of an arts-based research (ABR English Acronym = PBA Portuguese acronym). So it is important to clarify the acronyms, even though, paradoxically, we do not have conceptually moved on enough to be able to affirm clearly when we have stepped into "one" or "the other" research. An "educational" research based in the arts will, of course, have concerns pertaining to the educational territory, its actors and products, while a research (simply) based in the arts can be focused on other fields and other disciplines of knowledge not specifically concerned with education.

However, if on the one hand we consider education as a field that often goes beyond its own formal territory, seeking niches and gaps offered by artistic languages to be able to find more vibrant answers to the new educational problems, and on the other hand, we see in many artistic experiences an aesthetic extrapolation to the educational (albeit informal), then we must accept the osmosis between educational research based in the arts and research based in the arts. In fact, in many objects and research projects, these methods are not distinguishable. And that is because we are not able to predict where the aesthetic-artistic ends and the educational begins and vice versa in a resolutely transdisciplinary field of research characterized by its porosity and permeation. 


\section{SOCIAL CONSTRUCTIONISM AND THE NOTION OF “VOICE”}

The methodological perspective of "research based in the arts" is part of the epistemological field of social constructionism or a constructionist approach or, yet, as some authors call: constructionist paradigm (GUBA; LINCOLN, 1994; SCHWAND, 2006). By paradigm we are referring the "basic belief system or global perspective that guides the researcher, not only in the method of selection, but the fundamental ontological and epistemological questions of research" (GUBA; LINCOLN, 1994, p. 105). As for social constructionism we understand the field that aims to talk about how we conceive the world, inviting us to discuss the realities that are socially and locally built, given the subjective and cultural character of each subject. Adherents to this approach are the first to name it as a "non theory". What this perspective aims is to shift the notions of truth and all what we understand as real and true to compose a critical and flexible vision. Constructionism tries to reflect mainly on the social constructions that permeate everyday life, from the relations between culture, ideology, power, subjectivity, imagination and social representation regarding the understanding that we have of reality (GERGEN, 1999).

Social constructionism considers the discourse on the world not as a reflection or universal map, and thus proposes to go beyond simple empiricism and rationalism by relating knowledge within a process of social exchange. Gergen (1999) proposes four basic hypotheses to explain how people describe, explain or give meaning to the world in which they live. The assumptions are as follows:

1. Construction of concepts: what we consider knowledge of the world is not the product of induction or of building general hypotheses as was thought in positivism, but is determined by culture, history or social context. Example: expressions as "man" and "woman" are defined from a social point of view;

2. Enunciations: the terminologies with which we learn about the world are social artefacts, the product of exchanges and relationships between people, historically situated. The process of understanding is not automatically driven by nature, but results from an active and cooperative process of discursive communities. Example: the terms "childhood", "adolescence" and "old age" vary in their significance according to the historical period and the discursive communities taken into account;

3. Attitudinal stance: the force exerted by a particular form on social processes does not depend fundamentally on empirical forces over constructionism, but on the vicissitudes of social processes 
(communication, negotiation, conflict, etc.). Example: interpreting a conduct as frivolous, or diverted from the standards, may be suggested, confirmed or abandoned as social relationships develop over time. This negotiation of reality opens a way to a social epistemology;

4. Social Models: forms of negotiated understanding are connected with many other social activities. These forms of understanding (clichés or stereotypes) sustain and support certain standards and exclude others. To change descriptions and truths means to threaten certain actions and to value others. Example: the adjectives we create for regulate, label and name (man-machine, problem student, etc.).

The methodologies based on the constructionist paradigm, such as the case of the "research based in the arts," are intended to understand the complex world of lived experience from the perspective of those who live (SCHWANDT, 2006; VAN MANEN, 2003); a purpose that would be the base of the so-called "narrative perspective" (CONNELLY; CLANDININ, 1995, 2000; DENZIN, 1997) in research in Social Sciences and the Humanities. Among the research methodologies linked to this narrative character, we would highlight the perspectives based on ethnographic voices (CONNELLY; CLANDININ, 1995; CONLE, 1999), the life stories of teachers (GOODSON, 2004), auto-ethnography (SPRY, 2001; SOUMINEN 2006; VERSIANI, 2005) and the various perspectives related to research based in the arts (BARONE; EISNER, 2006; Hernández, 2008), a/r/graphy being one of them. What somehow moves all these investigative paths is the conviction that knowledge can also be derived from the experience. This statement has a range that the scope of this article does not enable us to explore, however, beforehand, we can say that, in this sense, the boundaries between who researches and the subject or research material are broken to give place to a complex web of relationships which is incorporated in the history/survey pathways. In the same way, the relationship between researcher and researched is visible. This implies replacing the different "voices" that nourish the narrative in a plan that dismisses the totalitarian narratives on knowledge and show where their silences and intermittences live. Another relevant issue is that the notion of experience situates knowledge beyond the "thinkable" and strictly thought. This implies access to what people do, not only to what people say they do (SILVERMAN 2000 cited by HERNÁNDEZ, 2008). Thus, with the focus put on experience, the notion of "voice" enters the perspectives of narrative research in such a way that it seems appropriate to devote a few lines to situate it in this text. 
According to Brizman (cited CONNELLY; CLANDININ, 1995), the concept of "voice" can be defined in the literal, metaphorical and political sense. In its literal sense, the "voice" is the speech and the perspective of the speaker. Metaphorically, the "voice" refers to the inflection, the tone, the accent, the style, attributes and feelings that express the words of the speaker. And from a political point of view, the "voice" is the right to speak and be represented/ear (BRIZMAN 1989 cited CONNELLY; CLANDININ 1995, p.1617). But the increasing use of the term extended between different narrative research approaches resulted in appropriations and uses not without controversy. The "voice", in many cases, instead of contributing to question the complexity of the research, the partiality and the real fragmentation and multiplicity of subjectivity at stake in this type of research, lent itself to a confessional and commiseration account. On the other hand, the very act of "giving voice" has a colonial germ that we should consider at least problematic.

The emphasis on voice is also, as stated by Eisner (1998, p. 18), a form of affirmation to let readers know that the author is present in the research and "not a disembodied abstraction that depersonalized itself through the linguistic conventions that hide his signature. "Also according to Eisner (1998, p. 18):

\footnotetext{
[...] Another reason to emphasize the voice and other tropes is not a claim to recharge the language to be "humanistic" or "artistic"; intended to serve epistemological interests. What we seek, and what we see or say, is influenced by the tools that we know how to use and deem appropriate. The language of propositions, this fundamental language for the empirical sciences [...] cannot imitate the impression of feeling life. For that feeling to communicate, we should use the language of the arts, because through the way a symbol manifests that feeling acquires real life. Therefore, the aim to fully explore the language is a way to do justice to what we have seen; it is a way to help readers attain knowledge.
}

In another perspective, Haw (2008) distinguishes between those issues that are linked to how the "voice" is articulated and is heard, and those issues that relate to how the "voice" is heard and questioned. With regard to the latter, Haw (2008, p. 203) distinguishes three types of voices: authorized, critical and therapeutic. Regarding the way the "voice" is articulated and is heard, Haw (2008) emphasizes four aspects that can serve as a summary of what was said earlier regarding the "voice": 1) Favour the experience, compared with the theory or training, as the basis of people's understanding of a topic or an activity, and the meaning that we grant it. This priority on the experience is based in "inner authenticity" which hardly can be demonstrated in the research; 2) Favours the deleted, silenced or subordinated "voices" compared 
to the dominant "voices" to start or drive change; 3) Recognizes the proliferation of multiple "voices" and the increasingly fragmented nature of the experiences and knowledge of the people; 4) It is conceptually tied to activist themes, participation and empowerment.

In the scope of narratives, the "voice", as well as being a keyelement, must be provided to all participants in the research process (researcher, reader, collaborator). It is in this conceptual field and with those initial markings that we place this methodological perspective, which we will later analyse in detail.

\section{ARTS-BASED RESEARCH. WHERE DOES IT COME FROM AND WHAT IS IT?}

Since the 70s and 80s in North America some researchers have been making attempts to explore another way of thinking about educational research methodologically. These attempts have generated research methodologies, as we will explore in this section. "Arts-based research" is not unique to the field of education; other areas such as anthropology, sociology and psychology have used this same method to carry out their research. This method has had wide acceptance in higher education institutions from different countries, including Brazil.

Thomas Barone and Elliot Eisner (2006) were the authors who systematized in the first decade of this century this new methodological field as a form of research aimed to increase our understanding of certain human activities through artistic means and processes.

"Arts-based-research emerged largely from a mismatch between what is produced and the attempt to frame it in scientific methods that do not include the writing style and technical standards adopted in the research. It is a kind of qualitative targeted research that uses artistic procedures, whether literary, scenic, visual or performative, to give an account of practical experiences in both the different subjects (researcher, reader, collaborator) as the interpretations on their experiences reveal aspects that are not visible in other types of research.

That is not the only possible definition. In fact, the incorporation of the arts in the broad umbrella of qualitative research orientation is beeing tried from many other different approaches. Fernando Hernández (2008) widely collected some of the most relevant: a/r/ tography (SPRINGGAY et al., 2008) which incorporates the research of visual, performative, poetic, musical and narrative forms of questioning; the position of Huss and Cwikel (2005), who consider art as a method, a way of analysis, a topic, or all of them together, within qualitative research; or the emphasis of Mason (2002) and Sclater (2003) in the value of the arts to connect ideological abstractions with 
specific situations, when considering that the use of drawings, stories, vignettes and photographs in research must respond to personal and collective elements of cultural experience that are not mere devices in an interview. In addition to these authors, the perspective of "artsbased research" can be located, according to Hernandez (2008), in other authors such as Mullen (2003), Silverman (2000), Kapitan (2003), Hervey (2000), McNiff (1998), Allen (1995) or Linesch (1995).

From that initial junction, that could even be larger, we extract that the space we reserve to the arts in an investigation is, at best, uneven - not to mention the meaning which the arts can contribute with to the investigation. In most studies of a narrative nature, ethnography remains the most common way to "observe" the lived. The "arts" are often seen as an "alternative" chance in order to account, to rebuild or communicate what is learned in the research. Thus, we may ask: in what cases can we speak in "arts-based research" and in which are the arts simply a punctual, isolated, complementary and residual strategy? Can we develop strategies for "registration" based on the arts? Or yet, what implications would this position have for research conducted in the field of education? From that point of view, we realize that what is at stake in these matters is not only the notion of "arts-based research", which we manipulate, but also our own notion of research, methodology, subjectivity or art (in the context of an investigation).

In this sense, we can think of some implications that we express, once again, in the form of questions: What is the place of "art" in "arts-based research"? What characterizes the arts in this context? What is their contribution and at what points in the investigation? How do we deal with images and for what purpose do we use it? To what extent are the arts a door that allows us to cross corners of the experience we had and that otherwise would be banned to us? We understand research as a way to discuss and formalize a curiosity that is personal/individual. And thus to see see what others have seen, but still have not observed; show that while it is visible to others it remains hidden. To read what others have read, but being able to, from the same references, say what no one has said or say it in another way. Or even, what I am able to say from what the author said?

So as to not remain in an overly theoretical ground, we collect some specific examples of what, according to Hernandez (2008), could be considered an "arts-based research":

- Visual essays, in which the images tell by themselves a story or dialogue (as opposed to illustrate) from a different plan to the one presented by the text; 
- Essays using different forms of literary narrative, transition experiences through education, to allow the reader to establish resonance with the text they were given;

- Investigations that show the process and outcome using unconventional forms of research, especially those with visual or performance resources.

The value of those examples depends on where we put the spotlight. In this sense we would like to demarcate the terms "visual essays," "forms of literary narrative" and "visual or performance." And so, according to the precautions we pointed out in the above questions, to call attention to the following: with regard to images, they necessarily need to "dialogue" with the text, "tensing it", i.e. put themselves in relation to the text and not to illustrate it or represent it. They should not be a decal, but establish maps with the text ${ }^{2}$. Establishing resonances means that the reader will not find a path to take. He or she will have to build it, to establish connections. And lastly, the production must be consistent with everything that has been thought during and at the end of the process and, therefore, unique in each case.

In this sense, what characterizes "arts-based research" is not the inclusion of images or literary texts, poems, drawings, etc., to compose the research, but how these materials and other forms of artistic representation are inserted in the research, where they are located and, above all, where do they locate ourselves as researchers and readers. It is, therefore, not about the use of certain methods or "artistic" practices, but to relate in "another sense" with what we investigate, to appropriate another kind of gaze that we recognize in the "artistic" and which allows us a glimpse of what would, by other methods, be impossible.

In the field of "arts-based research," we have talked a lot in "living research", what does that mean? It means that we care more what is in progress, what is in route during the process, the creation itself, than the data collected, samples, checks and data analysis or the very materiality of the research.

Our experience, as dissertations and thesis examiners, has shown us that often the obsession with method is such that the researcher gets stuck extensively explaining the method and its implications with long chapters that end up masking the materiality of the research. There is no doubt that, in all research, there is a prior epistemological position, a reference benchmark that inspires the way to approach and situate oneself in the research, but it must not override the research itself.

The arts-based research, seen from reports in which teachers tell their experiences and those of their students, could allow us and them to understand what the 
formal logical reasoning leaves aside: the human experience in their actions and intentions. Unlike advertised facts, and the abstract propositions of empirical speculation, narrative gets closer to the emotional and complex dimension of experience. It allows us, as Bolivar (1998) stated, to capture the richness of the meanings of human affairs: the desires, feelings, beliefs, and values we share and negotiate within the learning community where we build ourselves as subjects. Thus, reports on the experience of research proposals based on the arts can prove to be a critical mediator to help us develop a new look for the teachers as active agents in a complex social context. (UFG, 2011, p. 47).

If the research is built during the research process, it would be appropriate that the researcher recognized him or herself as someone that is built in the investigation. It follows that neither the researcher subject nor the methodology "precedes" the investigation, but both are constituted in and with its development. The distinction between researcher and researched in this type of methodological approach becomes weakened and dissipated.

The methodologies are therefore not watertight compartments, chapters aside, although their "scientific" definitions still speak about collecting data, subjects, data analysis, etc. If we agree that the methodology is built during research we should explore the hybrid nature of a methodological approach. To recognize that each survey has its own methodology, its own history, an history that can (and should) also be told.

\section{ON A/R/TOGRAPHY}

A/r/tography is a research methodology derived from "artsbased research", i.e., it is a practice of "research based in the arts", and also of narrative perspective that starts from the acronym a/r/t: "a" from artist, " $r$ " from researcher and " $t$ " from teacher. Whilst the term graphy in its Greek etymology ( $\varrho^{\alpha} \dot{\varphi} \varphi \iota \nu=$ graphein) means, "to write, graphically represent". Then, a/r/tography would be a kind of survey produced/accomplished by a researcher who also plays the role of teacher and artist concomitantly (understanding that the artist can be a musician, poet, dancer, actor, performer, sculptor, painter, etcher, etc.).

The main references and publications on a/r/tographycal approaches are the Faculty of Education at the University of British Columbia, Canada, as it was from the monitoring of 30 doctoral theses carried out between 1994 and 2004 that this method of research ${ }^{3}$ was developed.

In Brazil, there is little reference to a/r/tography, and by the year 2013 there were only a few scattered articles published in Portuguese on the subject. Most of them are authored by Belidson Dias (Brazilian, 
Professor at the University of Brasilia) and Rita Irwin (Canadian, Professor at the University of British Columbia), specifically in Dias (2009, 2011) and Irwin (2008). Belidson did his PhD in Canada, and Rita was one of the researchers of this group that monitored the thesis in the aforementioned period. In 2013, both launched in Brazil a book entitled: A Pesquisa Educacional Baseada em Arte: a/ r/tografia (Educational Research Based in Art: a/r/tography). It is the first book on the subject in the Portuguese language. It is a work organized on the theme, with several articles of researchers from different Brazilian and foreign universities that make use of this method and thereby detailing its peculiarities. The book provides examples of research and master and doctoral guidelines using this methodological approach.

$\mathrm{A} / \mathrm{r} /$ tography was designed from the studies of Elliot Eisner in the 70s and 80s at Stanford University in the United States, when the author tried to think about art as a basic element, fundamental to the

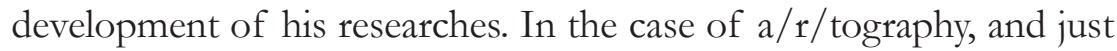
like in "arts-based research", art and writing do not separate, on the contrary, they complement each other, adhere and combine with each other. Image and text do not duplicate each other, but teach something different and, yet, also similar, allowing us to question more deeply about our practices as artists, as teachers and researchers as well.

A/r/tography brings a dynamic approach to qualitative research that challenges the naturalized and conservative notions of doing research; it starts from the critical perspective committed to the development of forms of interdisciplinary knowledge. It is a form of representation that favours both the text (written) and the picture (visual) when they are in moments of miscegenation or hybridization. It offers a range of methods which assist the processes of questioning, thinking and doing. It encourages new ways of thinking, approaching and interpreting theoretical/practical issues (DIAS, 2009).

How to dialogue, through research, with the artistic work (artist), the understanding (researcher) and the production of teaching knowledge (teacher)? In a/r/tography, to know, to do and to accomplish, merge and disperse, creating a mixed and hybrid language.

By putting creativity ahead in the in the process of teaching, research and learning, $\mathrm{a} / \mathrm{r} /$ tography generates innovative and unexpected insights to encourage new ways of thinking, to engage, and to interpret theoretical issues as a researcher, and practices as a teacher. The critical point of $a / r /$ tography is how to develop interrelations between artistic practice and the understanding of knowledge. (DIAS, 2013, p. 9-10)

Thus, a/r/tography looks for ways to accommodate images in their processes and products not only in their teaching/learning 
practices, but also in their practice of inquiry/questioning as a way to complement, or break with, the order of the written text.

A/r/tography offers another form of writing and creation within educational research with an emphasis on image, and the a/r/ tographer, practitioner of $\mathrm{a} / \mathrm{r} / \mathrm{tography}$, is promiscuous because he or she integrates these multiple and flexible roles in his or her professional life. It is not interested in identities, only in temporal, transient roles. It inhabits gaps, threshold spaces, third spaces and "places in between".

$\mathrm{A} / \mathrm{r} /$ tographers are living their work, are representing their understanding and are running their teaching practices and, while integrating theory, practice and creation through their aesthetic experiences, they "produce meaning" rather than facts and data.

$\mathrm{A} / \mathrm{r} /$ tographic perspective is constituted by means of visual and textual understandings and experiences that locate artistic production at the "centre of the research process" (IRWIN, 2008). This differs from most forms of educational research based in the arts, which merely give an account of research by "artistic representations." Unlike those methods that focus on outputs, " $\mathrm{a} / \mathrm{r} /$ tography is based on questioning (search mode, enquiring and problematizing) with the conviction that this can be informed by and through the arts" (SPRINGGAY, 2008 p. 37).

And why should we adopt this methodological perspective on research in the educational field? A/r/tography (artist/researcher/ teacher) invites educators to rethink their multiple subjectivities (as artists, researchers and teachers) not as separate entities but as "organisms that may come into collision, in order to explore the way in which meanings, understandings and theories generated multiply, are interwoven and complicated "(SPRINGGAY, 2008, p. 37).

We now present six forms of interpretation and ways of operating in educational research through which a/r/tography is articulated (SPRINGGAY 2008, p. 38-43 synthesis,). These items serve as a first approach to the analysis of artistic processes:

1. Contiguity: are the ideas of the search that are born twinned, that are born together, touching each other, or that are in a mutual presence: art and handwriting, for example;

2. Lively questioning: is embodied in the experience, in a such way that the educational phenomenon we investigate is intertwined with our own perceptions of the world and ourselves;

3. Openings: a/r/tography is a way of thinking about how to theorize the multiplicity. It has nothing to do with the definition of milestones or the understanding of principles, but with facilitating inter-corporal meetings. The openings allow the contradictions 
and resistance embodied in vivid questioning that takes place in contiguity. These openings produce discontinuities that resist predictability, comfort and security.

4. Metaphor and metonymy: instead of pursuing the certainty of logic and the guarantee of universal validation, a/r/tography is involved in imagination, experimentation, the uniqueness and the conjecture. These are forms of openness seeking to provoke and generate meaning through the frequent use of metaphorical and metonymic relations (It is called a metonymy or trans-nomination a figure of speech which involves the use of a term instead of the other, given the similarity ratio or the possibility of association between them).

5. Reverberations: through links/bonds and creative winding/ zigzagging connections, the reverberations build meaning as a space "between" the parts indicating variations, discontinuities and complexities.

6. Excess: The excess is evocation, provocation; something that challenges us from what we cannot yet name. Excess creates a supplement, an overflow "which makes possible a multi-resistant reading and prevents the reproduction of the same meaning or sense through successive readings of a word or event" (Millar, 2005, p. 128, cited SPRINGGAY, 2008 p. 41-42).

Thus, as we can see, the a/r/tographic research cannot be understood from a traditional scientific perspective, since it brings in its wake many tributaries that perform in a particular way.

Rita Irwin (2013) warns that the a/r/tographic research method has many and deep relationships with action-research because, like the latter, it also has an interventionist character that makes it a living practice, in which the very practices of teachers and artists become places/environments of research.

\section{RESONANCES OF WHAT REMAINS}

Now, moving towards a completion of this text, and in an attempt to think about the contributions for research in education of both methodological perspectives - the "arts-based research" in a broader sense, and "a/r/graphy" in particular - we allow ourselves to add some further comments.

Perhaps the greatest argument for the adoption of these methods is to assume that research is a path built in the course of the investigation itself and that in this case there is no previous methodology to the existence of the process, that is; it is not about having an a priori research methodology on which to base 
the research, it is exactly the opposite. It is the process that will set the methodology. The research as a process, and the process as a continuous sequence of events or transactions, that may lead to other sequences of events or operations, i.e. the research as a journey. This implies permanent disruption of the established equilibrium. Doing research under these conceptions is to be in constant motion, in the process, in route. In this type of research it will be the reader who will have to establish the links, do the trail, because the path is not given in advance. The sense will not be presented by the researcher; it will need to be built by the reader. These are researches that often are more collaborative buildings, collective discourse communities than individual copyright/original routes.

Both approaches allow us to have a relationship with the image that no other approach to date had enabled us to, and that relationship is beyond the complement. It is a continuing process of docking and undocking. It is a composition process.

Another point worth mentioning is the rigor that these methods require. Be deceived those who, perhaps, may think that, because it is "art", everything is permitted. Rather, in addition to all the demands that an investigative process requires, it walks in parallel to artistic production, which must be born together, grow in tandem and dialogue with the modus operandi along the way.

The research produced in the field of education, from constructionist paradigm methodologies, as in the case of both that were discussed in this paper, has been widely accepted in academia and is here to be scrutinized. It is up to us to take it as one more methodological possibility, or refute it as a method for being ineffective.

Consequently, it is worth opening the opportunity to use these new methodological perspectives in advanced training (masters and doctorate), but not as the only way forward, or one that is supposedly more fashionable. On the contrary, the ability to search from these perspectives implis, on the part of the researcher, concrete knowledge of forms, processes and "philosophies" that frame the more traditional methodologies, to finally realize the specificity that limits these alternative ways of doing research. These are precisely the forms that accept the experience and the lived by the researcher, as an important part of the process. This fact transforms research into a form of storytelling that prefers more to account for the richness and uniqueness of human experience than to highlight the universalization and standardization of some sort of knowledge that, in a sense, would be expected from the traditional research questions made at the beginning of the research process. 
Like any new approach, it needs time to consolidate itself, produce its products and be open to evaluation. In Brazil, there are a few higher education institutions that have produced research from Arts-based Research and a/r/tography.

When we refer to the „resonances of what is left" to finalize this text, we think about our journey in the supervision of dissertations and thesis. Resonances are what remains from an experience or what keeps coming back to our memory or our body.

The resonance is not based on fragments that were provided by the partial objects nor totalizes pieces that come from somewhere else. It draws its own pieces and makes them resonate according to their specific purpose, but not totalizing them, as it is always a "body-to-body fight", a "struggle" or a "combat". What is produced by the resonance process, in the resonating machine, is the singular essence, the point of view superior to the two movements that resonate, breaking with the associative chain that goes from one to the other (Deleuze, 2010, p. 144).

What remains in our body as material trace of that experience with these new methodologies, and that we took as a trigger to produce this text, was a sign that put our thoughts in motion and forced us to think, not from fragments but from our own pieces.

We had to confront ourselves with our beliefs, our dogmas and our prejudices and face them. After all, it is not always easy to do in a different what we have been doing in the same way over years. To singularize. To put the authors in dialogue with the research process and to produce another form of writing, producing ourselves as researchers together with the research.

\section{REFERENCES}

BARONE, T.; EISNER, E. Arts-Based Educational Research. In: GREEN, J.; CAMILLE, G.; BELMORE, P. Handbook of Complementary Methods in Educacional Research. Mahwah, New Jersey: AERA, 2006. p. 95-109.

CONNELLY, M.; CLADININ, J. Stories of Experience and Narrative Inquiry. Educational Researcher, Mahwah, New Jersey, v. 19, n. 5, p. 2-14, 2000.

CONNELLY, M.; CLANDININ, J. Relatos de Experiencia e Investigación Narrativa. In: LARROSA, J. Déjame que te cuente. Ensayos sobre narrativa y educación. Barcelona: Laertes, 1995. p. 11-60.

CONLE, C. Why Narrative? Which Narrative? Struggling with Time and Place in Life and Research. Curriculum Inquiry, Mahwah, New Jersey, v. 29, n. 1, p. 7-32, 1999.

DELEUZE, G.; GUATTARI, F. Mil Platôs. Capitalismo e esquizofrenia. v. 1. Rio de Janeiro: 34, 1995. DELEUZE, G.; GUATTARI, F. Proust e os signos. Tradução de Antonio Piquet e Roberto Machado. 2. ed. Rio de Janeiro: Forense Universitária, 2010. 
DENZIN, N. Ethnographic poetics and narratives of the self. In: Interpretative Ethnography. London: Sage, 1997.

DIAS, B. Uma epistemologia de fronteiras: minha tese de doutorado como um projeto a/r/ tográfico. Anais... 18. Anpap. Salvador, Bahia, 2009. p. 3173-3187.

DIAS, B. O i/ mundo da Educaşão em Cultura visual. Brasília: UnB, 2011.

DIAS, B. A/r/tografia como metodologia e pedagogia em artes: uma introdução. In:

DIAS, B.; IRWIN, R. (Org.) Pesquisa Educacional Baseada em Arte: a/r/tografia. Santa Maria: Edufsm, 2013. p. 6-12.

EISNER, E. W. El ojo ilustrado: indagación cualitativa y mejora de la práctica educativa. Barcelona: Paidós, 1998.

GERGEN, K. An invitation to social construction. London: Sage, 1999.

GOODSON, I. Historias de vida de profesorado. Barcelona: Octaedro, 2004.

GUBA, E.; LINCOLN, Y. Competing Paradigms in Qualitative Research. In: DENZIN, N.; LINCOLN, Y. [ed.] Handbook of Qualitative Research. London: Sage, 1994. p. 105-117.

HAW, K. Voice and video. In: THOMSON, P. [ed.] Doing Visual Research with Children and Young People. London \& New York: Routledge, 2008.

HERNÁNDEZ, F. La investigación basada en las artes: propuestas para repensar la investigación en educación. Educatio Siglo XXI, Revista de la Facultad de Educación de la Universidad de Murcia, v. 26. 2008. p. 85-118.

IRWIN, R. A/r/tografia: uma mestiçagem metonímica. In: BARBOSA, A. M.; AMARAL, L. (Org.) Interterritorialidade: mídias, contextos e educação. São Paulo: SENAC, 2008. p. 87-104.

IRWIN, R. A/r/tografia: uma introdução. In: DIAS, B.; IRWIN, R. (Org.) Pesquisa Educacional Baseada em Arte: a/r/tografia. Santa Maria: Edufsm, 2013. p. 13-23.

SCHWANDT, T. Três posturas epistemológicas para a investigação qualitativa: interpretativismo, hermenêutica e construcionismo social. In: DENZIN, N.; LINCOLN Y. (Ed.). O planejamento da Pesquisa Qualitativa, teorias e abordagens. 2. ed. Porto Alegre: Artmed, 2006. p. 193-217.

SOUMINEN, A. Writing with photographs writing self: Using artistic methods in the investigation of identity. International Journal of Education through Art. New York, v. 2, n. 2, p. 139-156, 2006.

SPRINGGAY, S. Body Knowledge and Curriculum. Pedagogies of Touch in Youth and Visual Culture. New York: Peter Lang Publishing, 2008.

SPRY, T. Performing Autoethnography: An Embodied Methodological Praxis. Qualitative Inquiry, New York, v. 7, n. 6, p. 606-732, 2001.

UNIVERSIDADE FEDERAL DE GOIÁS. Faculdade de Artes Visuais. Licenciatura em Artes Visuais: módulo 8. Goiânia: FUNAPE, 2011.

VAN MANEN, M. Investigación educativa y experiencia vivida. Barcelona: Idea books, 2003.

VERSIANI, D. B. Autoetnografias - conceitos alternativos em construção. Rio de Janeiro: 7 letras, 2005.

\section{NOTES}

${ }^{1}$ We kept all the methodological terms and designations in the mother tongue to be consistent with the acronym used. 
${ }^{2}$ The concepts of "decal" and "map" are referenced from Deleuze (1995, p. 21-22). Decal corresponds to something already done, from a structure that's overcodify and that reproduces itself, while map is supported on constant experimentation and presents a variable form.

${ }^{3}$ To extend, access: <http://m1.cust.educ.ubc.ca/artography/\#>.

Received: $14 / 09 / 2014$

Approved: $14 / 04 / 2015$

Mailing:

Marilda Oliveira de Oliveira

Rua Elvino Brondani, 171

Parque Residencial Novo Horizonte Camobi

Santa Maria $\mid$ RS |Brasil

CEP 97.110-850 
